\title{
EKSISTENSI MEDIA DALAM PEMBELAJARAN MELALUI MEDIA SOSIAL DAN MEDIA AUDIOVISUAL DI FAKULTAS KEGURUAN DAN ILMU PENDIDIKAN (FKIP) UNIVERSITAS PRIMA INDONESIA
}

\author{
Rony Arahta Sembiring, Ermina Waruwu \\ Surel: ronyarahtas@gmail.com
}

\begin{abstract}
This study aims to identify learning outcomes through the media used by students, focus student knowledge to determine the contribution of media in their learning, improve student expertise / knowledge, and provide opportunities for students to become innovative teachers. This research method applies descriptive qualitative data analysis and comparative quantitative. The research data was measured through test and non-test instruments. The research sample was FKIP students majoring in Indonesian and English through 2 general subjects, namely learning media and educational statistics. The results of the study have shown that the learning outcomes of the two majors do not show a significant difference. Furthermore, 24 questionnaire items showed that social media contributed more to student learning activities than audiovisual media. On the other hand, the observations show that students are more likely to behave negatively during research activities. Students feel uncomfortable if learning activities are dominated by media. Plus the imposition of online learning which requires virtual learning activities. So this research concludes that the existence of the media will be increasingly felt if it is collaborated with other relevant learning methods.
\end{abstract}

Keywords: Media, Learning, Existence, FKIP Students

\begin{abstract}
ABSTRAK
Penelitian ini bertujuan untuk mengidentifikasi capaian belajar melalui media yang digunakan mahasiswa, memfokuskan pengetahuan mahasiswa untuk mengetahui kontribusi media dalam pembelajarannya, meningkatkan keahlian/ keilmuan mahasiswa, dan memberikan peluang mahasiswa menjadi guru yang inovatif. Metode penelitian ini menerapkan analisis data secara deskriptif kualitatif dan komparatif kuantitatif. Data penelitian diukur melalui instrumen tes dan nontes. Sampel penelitian adalah mahasiswa FKIP jurusan Bahasa Indonesia dan Bahasa Inggris melalui 2 mata kuliah umum yaitu media pembelajaran dan statistika pendidikan. Hasil penelitian telah menunjukkan bahwa hasil belajar kedua jurusan tidak menunjukkan perbedaan yang signifikan. Selanjutnya 24 butir angket menunjukkan bahwa media sosial lebih berkontribusi dalam aktivitas belajar mahasiswa dibandingkan media audiovisual. Di sisi lain, hasil pengamatan menunjukkan bahwa mahasiswa lebih cenderung berperilaku negatif selama aktivitas penelitian. Mahasiswa merasa tidak nyaman jika aktivitas belajar didominasi oleh media. Ditambah lagi diberlakukannya pembelajaran daring yang mengharuskan aktivitas belajar maya. Jadi penelitian ini menyimpulakan bahwa eksistensi media akan semakin dirasakan jika dikolaborasikan dengan metode pembelajaran relevan lainnya.
\end{abstract}

Kata Kunci: Media, Pembelajaran, Eksistensi, Mahasiswa FKIP 



\section{PENDAHULUAN}

Perkembangan

ilmu

pengetahuan telah dimulai sejak manusia mengetahui adanya kebutuhan yang harus dipenuhi dalam hidupnya. Sampai saat ini hasrat manusia yang begitu besar akan pemenuhan kebutuhan hidupnya merupakan alasan utama mengapa dinamika kehidupan tidak dapat diprediksi secara tepat. Oleh sebab itu, kajian tentang media perlu dilakukan untuk mengukur pencapaian ilmu pengetahuan manusia.

Penelitian ini berfokus pada penggunaan media dalam pembelajaran, sehingga mahasiswa FKIP dijadikan objek penelitian untuk mengetahui kontribusi media tersebut. Penggunaan media oleh guru sudah begitu signifikan dalam pembelajaran. Saat ini sudah banyak sumber belajar yang tersedia secara independent baik melalui aplikasi elektronik seperti book reader by scaning access, komunitas belajar online, maupun materi pelajaran praktis lainnya melalui aplikasi smart phone yang dilakukan secara daring.

Hal ini sudah disadari pemerintah melalui renstra Kemendikbud (2015-2019) yakni terdapat satu (misi ke-3) dari lima misi yang berisi adanya perwujudan pembelajaran bermutu. Dan jika ditambahkan lagi pada rentang renstra tersebut terdapat gerakan literasi yang dicanangkan pada tahun 2016 oleh Kemendikbud yakni adanya literasi teknologi dan informasi yang mengharuskan pembelajar mampu mengelola informasi ter-update, mengikuti perkembangan teknologi melalui computer literacy dan memanfaatkan teknologi untuk meningkatkan potensi yang dimiliki penggunanya. Apalagi saat ini dinamika insdustri 4.0 sedang intens dieksplorasi oleh banyak lembaga. Maka sudah selayaknya pemahaman tentang media tidak hanya sebatas instrumen saja, tetapi harus menjadi bagian dari kehidupan professional guru secara terintegritas sehingga memberikan dampak yang inspiratif bagi setiap pembelajar. Sebagaimana Budiningsih (2005:5) melalui teori belajarnya menyatakan bahwa "peserta didik adalah manusia yang identitas insaninya sebagai subjek berkesadaran perlu dibela dan ditegakkan lewat sistem dan model pendidikan yang bersifat bebas dan egaliter".

Media pembelajaran dapat dijadikan sebagai perantara atau pengantar terjadinya interaksi (komunikasi) dari pengirim menuju penerima dalam sistem pembelajaran yang dibangun (Heinich et.al.,2002; Ibrahim, 1997; Ibrahim et.al.,2001). Jika dikaitkan dengan hasil Seminar Sehari Internasional Penggunaan Media Digital di kalangan Anak dan Remaja Indonesia oleh Kominfo dan didanai UNICEF yang diselenggarakan 18 Februari 2014 di Jakarta menyimpulkan bahwa 98\% dari 400 anak-anak dan remaja (10-19 tahun) yang disurvei tahu tentang internet dan 79,5\% diantaranya adalah pengguna internet. Maka media sebagai perantara dapat dijadikan indikator yang mempengaruhi 
aktivitas belajar siswa dan menjadikannya sebagai sarana praktis dalam berinteraksi dengan lingkungannya. Sehingga dengan adanya fenomena ini profesi guru perlu memahami keberadaan dan penggunaan media dalam pembelajaran secara kompleks serta mampu mengimplementasikannya melalui kinerja. Oleh karena, telah teridentifikasikan beberapa masalah diantaranya: perkembangan ilmu pengetahuan yang belum disertai perkembangan pembelajaran secara optimal oleh calon guru (mahasiswa), adanya indikasi penggunaan media dalam pembelajaran yang dibatasi oleh agen pendidikan, rendahnya daya tanggap calon guru dalam memanfaatkan media pembelajaran yang inovatif. Dengan demikian dalam penelitian ini akan dieksperimentasikan beberapa bentuk kasus yang dijadikan sebagai objek dan sarana guna mengetahui pemecahan masalah tersebut terkait media pembelajaran.

Adapun media dalam pembelajaran yang akan dieksplorasi dalam penelitian ini adalah media sosia dan audiovisual. Kaplan \& Andreas M (dalam Michael Haenlein, 2010) mempertegas bahwa "media sosial adalah sebuah kelompok aplikasi berbasis internet yang membangun di atas ideology dan teknologi dan memungkinkan penciptaan dan pertukaran usergenerated content". Oleh sebab itu melalui media sosial pendidik dapat mengaktualisasikan diri sebagai professional, membentuk ruang baru yang dapat meningkatkan intensitas interaksi belajar, menjalin hubungan pribadi, dan tentunya memberikan peluang bagi pendidik untuk mempromosikan dan memasarkan keahliannya kepada masyarakat yang membutuhkan.

Di sisi lain media audiovisual juga dieksplorasi untuk mengetahui efektivitas media dalam pembelajaran. Sebagaimana Wina Sanjaya (2012: 204) menyatakan bahwa media pembelajaran dijadikan sebagai alat untuk memberikan perangsang bagi peserta didik supaya terjadi proses belajar yang dieksplor melalui indera pendengaran dan penglihatan. Maka tentunya optimalisasi pemanfaatan media pembelajaran perlu dilakukan karena adanya relevansi media pembelajaran sebagai stimulus dan indera sebagai alat perespon.

Selanjutnya penelitian ini juga memiliki beberapa tujuan diantaranya: mengidentifikasi capaian hasil belajar melalui media yang digunakan oleh calon guru, memfokuskan pengetahuan calon guru untuk mengetahui kekuatan dan kelemahan dengan media yang relevan dalam pembelajarannya, meningkatkan kualitas mengajar calon guru sesuai dengan bidang keahlian/ keilmuannya, dan memberikan peluang bagi calon guru untuk memproduksi suatu pembelajaran yang inovatif.

\section{METODE PENELITIAN}

Populasi penelitian ini adalah mahasiswa FKIP semester 6. Jumlah populasi sebanyak 240 mahasiswa yang jumlahnya akan direduksi 
melalui teknik penarikan sampel secara probabilitas, Menurut Setiawan Nugraha (2007:9) apabila penelitian bertujuan menduga proporsi populasi, maka ukuran sampel ditentukan dengan rumus Krejcie-Morgan dan hasilnya diperoleh 148 sampel mahasiswa FKIP yang kemudian didistribusikan ke dalam dua jurusan yaitu Bahasa Indonesia dan Bahasa Inggris. Masing-masing terdiri atas 74 sampel dan akan diteliti melalui mata kuliah media pembelajaran dan statistika pendidikan.

Adapun desain penelitian ini menerapkan metode survey dan akan dianalisis secara deskriptif kualitatif dan komparatif kuantitatif. Oleh sebab itu, pengukuran yang digunakan dalam penelitian ini adalah tes dan nontes. Pengukuran tes dilakukan dengan pilihan ganda pada setiap mata kuliah, dan pengukuran nontes dilakukan dengan angket dan observasi pada masing-masing jurusan. Dan untuk instrumen tes, peneliti telah mengkalibrasi kelayakannya secara matematis dan menelaahnya Bersama para ahli.

Penelitian ini dilaksanakan di tengah-tengah pandemic covid-19, sehingga sebagian besar aktivitas penelitian dilakukan secara daring (dalam jaringan). Sehingga beberapa instrumen penelitian disebar melalui tautan ini dan menggunakan aplikasi google form.

\section{HASIL PENELITIAN DAN PEMBAHASAN}

Penelitian ini dianalisis dahulu secara deskriptif, mulai dari deskriptif hasil tes pilihan ganda hingga deskriptif hasil observasi. Masingmasing hasil deskriptif diperoleh berdasarkan media yang digunakan dalam pembelajaran pada setiap mata kuliah. Untuk media audiovisual akan diukur menggunakan instrumen tes pilihan ganda, sedangkan untuk media sosial diukur menggunakan instrumen angket dan observasi. Selanjutnya, hasil penelitian dibahas berdasarkan teknik analisis yang telah ditentukan pada metode penelitian ini.

Adapun data deskriptif penelitian ini adalah pertama, data hasil tes pilihan ganda. Peneliti memperoleh bahwa hasil belajar pada kedua jurusan untuk masing-masing mata kuliah berbeda. Hasil penelitian menunjukkan rata-rata setiap kelas adalah 70,86 dan 70,45 untuk mata kuliah media pembelajaran dan mata kuliah statistika pendidikan rataratanya adalah 65,59 dan 67,86. Berikut ringkasan data hasil penelitiannya.

Tabel 1. Deskriptif Tes Pilihan Ganda

\begin{tabular}{ccccc}
\hline \multirow{2}{*}{ Parameter } & \multicolumn{2}{c}{ Media Pembelajaran } & \multicolumn{2}{c}{ Statistika Pendidikan } \\
\cline { 2 - 5 } & $\begin{array}{c}\text { Bahasa } \\
\text { Indonesia }\end{array}$ & $\begin{array}{c}\text { Bahasa } \\
\text { Inggris }\end{array}$ & $\begin{array}{c}\text { Bahasa } \\
\text { Indonesia }\end{array}$ & $\begin{array}{c}\text { Bahasa } \\
\text { Inggris }\end{array}$ \\
\hline Mean & 70,86 & 70,45 & 65,59 & 67,86 \\
\hline Median & 70 & 70 & 65 & 68 \\
\hline Varians & 94,53 & 30,14 & 95,23 & 71,21 \\
\hline S.Baku & 9,72 & 5,49 & 9,76 & 8,44 \\
\hline $\begin{array}{c}\text { Nilai } \\
\text { Terendah }\end{array}$ & 90 & 82 & 82 & 88 \\
\hline $\begin{array}{c}\text { Nilai } \\
\text { Tertinggi }\end{array}$ & 51 & 58 & 45 & 55 \\
\hline
\end{tabular}

Hasil di atas diperkuat dengan distribusi ringkasan nilai melalui gambar 1 dan 2 diagram batang berikut ini: 


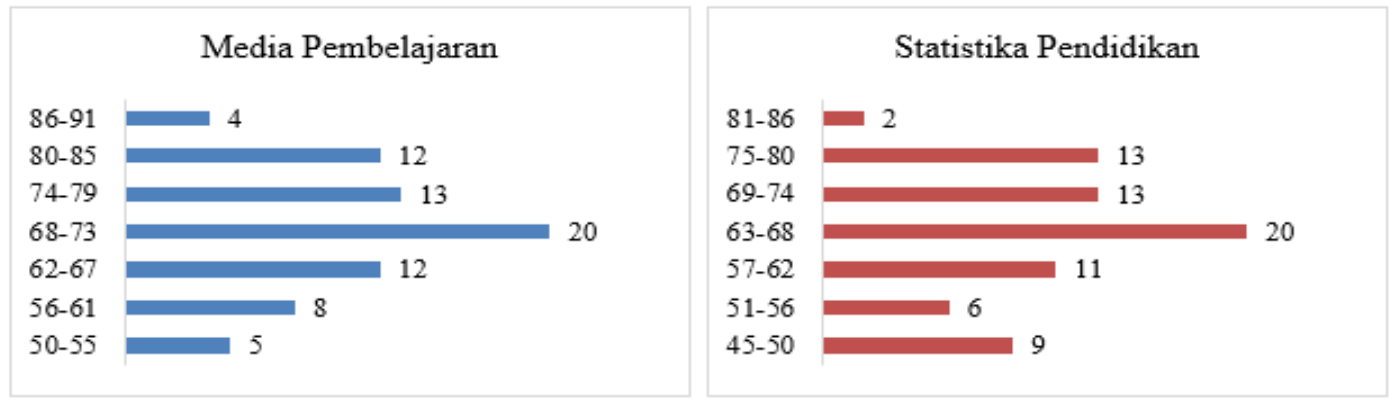

Gambar 1: Hasil Belajar Mahasiswa Pendidikan Bahasa dan Sastra Indonesia
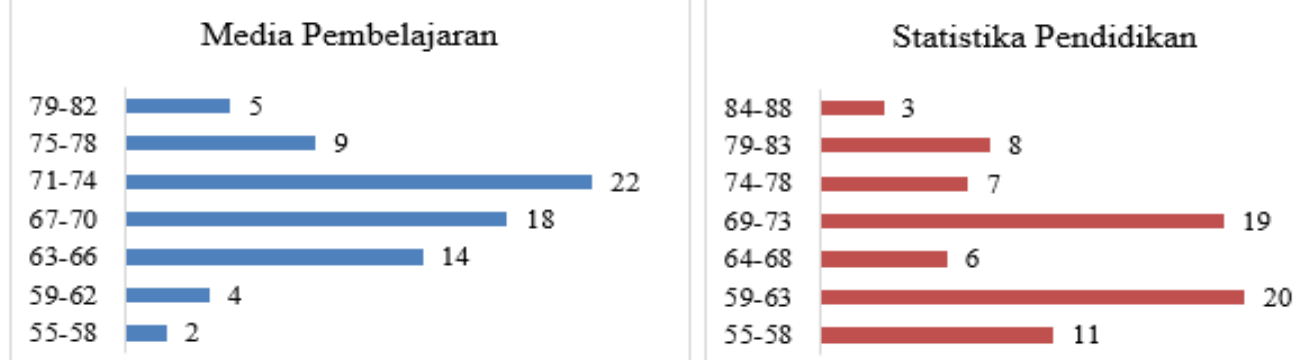

Gambar 2: Hasil Belaiar Mahasiswg Pendidikan Bahasa Inggris.

Berdasarkan kedua gambar di atas maka dapat diketahui distribusi frekuensi nilai mahasiswa memiliki pusat data yang berbeda. Namun berdasarkan analisis komparatif kuantitatif dapat dibuktikan bahwa tidak terdapat perbedaan hasil belajar antar jurusan pada masing-masing mata kuliah tersebut. Hasil tersebut diperoleh dengan mengolah data melalui SPSS 25. Uji hipotesis membuktikan bahwa kedua mata kuliah ini sama - sama menerima $\mathrm{H}_{0}$. Hasil uji ini memperoleh bahwa harga sig. setiap mata kuliah yaitu 0,747 dan 0,132 lebih besar dari harga $\alpha=0,05$. Sehingga meskipun nilai dan rata-rata hasil belajar mahasiswa setiap jurusan berbeda, tetap saja kemampuan mahasiswa pada kedua mata kuliah ini relatif sama.

Selanjutnya, hasil angket menunjukkan gambaran bahwa secara individualitas mahasiswa cenderung setuju tentang adanya media social dan audiovisual akan memberikan kontribusi postif dalam perkuliahan mereka. Namun demikianpun, hasil skor akhir kedua jurusan ini tampaknya telah menunjukkan perbedaan yang signifikan. Peneliti memperoleh bahwa rata-rata keseluruhan skor angket Pendidikan Bahasa Indonesia ternyata lebih tinggi dibandingkan skor Pendidikan Bahasa Inggris. Hasil penelitian menunjukkan rata-rata skor masing-masing jurusan yaitu 258,54 dan 262,25. Peneliti menemukan bahwa secara kualitatif kesimpulan hasil angket mahasiswa Pendidikan Bahasa Inggris berada pada kriteria tidak tahu $(258,54)$ sedangkan angket Pendidikan Bahasa dan Sastra Indonesia berada pada kriteria setuju $(262,25)$. Hal ini dapat diperkuat dengan jumlah total frekuensi pilihan mahasiswa pada angket penelitian berikut: 
Tabel 2. Frekuensi Pilihan Angket

\begin{tabular}{cccccc}
\hline Jurusan & SS & S & TT & TS & STS \\
\hline $\begin{array}{c}\text { Bahasa } \\
\text { Inggris }\end{array}$ & 1045 & 3896 & 465 & 722 & 77 \\
\hline $\begin{array}{c}\text { Bahasa } \\
\text { Indonesia }\end{array}$ & 960 & 4292 & 300 & 662 & 80 \\
\hline
\end{tabular}

Dengan demikian dapat diasumsikan bahwa mahasiswa jurusan Pendidikan Bahasa dan Sastra Indonesia memiliki kecenderungan setuju terhadap aktivitas perkuliahan yang diselenggarakan oleh dosen selama penelitian dibandingkan jurusan Pendidikan Bahasa Inggris.

Hasil penelitian juga diukur menggunakan observasi dan diperoleh bahwa perilaku mahasiswa dapat dipengaruhi oleh metode perkuliahan yang diselenggarakan oleh dosen. Dan pada kasus ini, tampaknya media social dan audiovisual cukup memberikan pengaruh terhadap perilaku belajar mahasiswa, terutama pada masa pandemic ini. Peneliti melihat bahwa mahasiswa sebenarnya memiliki hasrat belajar yang tinggi, hal itu terlihat ketika antusias mereka untuk menanyakan materi yang akan diujiankan dan mereka juga sering mengkonfirmasi/ berdiskusi terkait tugas-tugas yang telah diberikan oleh dosen. Jadi berdasarkan hasil observasi ini menunjukkan keberadaan media social dan audiovisual dalam pembelajaran perlu dioptimalkan lagi melalui variabel lainnya seperti ketepatan pemilihan model pembelajaran, kesesuaian bidang kajian/ keilmuan yang akan dibelajarkan dan tentunya akan semakin optimal jika dilaksanakan bersamaan dengan tatap muka di kelas.

\section{Pembahasan}

Berdasarkan hasil deskriptif dan analisis penelitian di atas maka pembahasan akan menitikberatkan pada penjelasan kondisi akhir penelitian ini. Hasil penelitian telah membuktikan bahwa nilai belajar mahasiswa (calon guru) masih relatif rendah, motivasi berprestasi belajar mahasiswa juga masih rendah. Padahal penggunaan media social dan audiovisual bukanlah sarana yang baru dalam pembelajaran. Apalagi kematangan mahasiswa dalam memanfaatkan media ini seharusnya meningkatkan antusias untuk mengeksplorasi ilmu pengetahuan secara menyeluruh. Peneliti berasumsi bahwa hubungan perkembangan ilmu pengetahuan dengan perkembangan pembelajaran sangat dipengaruhi oleh kondisi/ situasi lingkungan mahasiswa itu sendiri dan hubungan ini tampaknya tidak dapat diukur melalui perolehan nilai belajar mahasiswa saja. Artinya ilmu pengetahuan (nilai belajar) yang diperoleh mahasiswa harus dioptimalkan melalui kontribusi komponen pembelajaran (media) lainnya guna mengakomodasi mahasiswa untuk menguasai materi yang diajarkan. Dan sebaiknya optimalisasi komponen pembelajaran (media) tidak mengacu pada kecanggihan teknologi yang digunakan melainkan lebih mengutamakan fungsinya secara terpadu dalam pembelajaran. Oleh sebab itu, berdasarkan hasil penelitian ini menunjukkan bahwa eksistensi media social dan audiovisual dalam pembelajaran tidak menjadi factor 
utama dalam meningkatkan prestasi belajar.

Penggunaan media pembelajaran secara berlebihan juga berdampak pada proses perkembangan karakter mahasiswa. Hal tersebut pernah terjadi dalam percakapan media social, yakni setelah 5 pertemuan berlangsung terdapat beberapa mahasiswa yang berkomunikasi kurang santun dalam forum media social (contoh: mengirim gambar/ tulisan yang bersifat menyindir), mahasiswa juga menjadi malas untuk mencatat materi perkuliahan sebab seluruh materi belajar sudah ada pada media audiovisual dan mahasiswa dapat mengulangnya kembali. Hal lainnya juga dapat mengubah perilaku belajar mahasiswa menjadi tidak inovatif, kreatif dan dinamis. Sehingga penggunaan media pembelajaran perlu dibatasi oleh pendidik (dosen) agar mahasiswa (calon guru) dapat memahami kompetensi paedagoginya. Jadi, peneliti meyakini bahwa penggunaan media social dan audiovisual perlu diselaraskan dalam pengajaran supaya terdapat keseimbangan antara ilmu pengetahuan dan karakter (akhlak) mahasiswa sebagai calon pendidik yang berkualitas.

Peneliti juga membahas tentang adanya faktor internal mahasiswa (calon guru) dalam memanfaatkan media pembelajaran. Faktor ini berkaitan dengan daya tanggap mereka dalam menggunakan media social dan audiovisual. Peneliti melihat rendahnya perhatian mahasiswa untuk mengeksplorasi fungsi media social dan audiovisual selama pembelajaran. Mereka tidak bersungguh-sungguh memberdayakan media ini, bahkan terdapat mahasiswa yang sama sekali tidak pernah turut dalam forum diskusi kuliah. Dan pada akhirnya, tak satupun tugasnya yang berakhir dengan sempurna.

Rendahnya daya tanggap mahasiswa (calon guru) dinilai dapat mempengaruhi eksistensi media dalam pembelajaran. Terutama dalam memanajemen pembelajaran yang akan dikerjakannya ketika menjadi guru nantinya. Jika mahasiswa (calon guru) tidak tanggap dengan keberadaan media ini maka sangat dimungkinkan materi ajar yang akan disusunnya tidak terimplementasi sesuai rancangan pembelajarannya. Apalagi saat ini (masa pandemic), perkembangan teknologi sangat signifikan dalam pembelajaran. Hampir semua Lembaga pendidikan menggunakan aplikasi berbasis media/ elektronik, maka wajarlah mahasiswa untuk tanggap dengan setiap sistem/ media yang digunakan dalam perkuliahan.

Pembahasan di atas tentu didapatkan berdasarkan analisis peneliti yang subjektif. Mulai dari deskriptif penelitian hingga analisis data hasil penelitian maka kita dapat menyimpulkan bahwa arah dan kontribusi media social dan audiovisual dalam pembelajaran perlu diukur terlebih dahulu, agar ilmu pengetahuan yang diakomodasi dapat berkembang secara signifikan. Oleh sebab itu, penelitian ini telah 
membuktikan bahwa eksistensi media dalam pembelajaran perlu diuji kesesuaiannya pada materi yang dibelajarkan dan kondisi pembelajarnya.

Pembahasan ini juga menunjukkan ketidaktercapaian mahasiswa untuk dapat menghasilkan dan menginovasi pembelajaran melalui media yang mereka ciptakan sendiri. Peneliti meyakini adanya pengaruh pandemic yang terjadi sampai saat ini mengakibatkan produksi media dan pemantapan fungsi ruang media oleh mahasiswa tidak berjalan sesuai rencana. Dan situasi selama penelitian juga telah mengintimidasi mahasiswa untuk tidak beraktivitas secara normal, sehingga eksistensi media yang dimaksud dalam penelitian ini menjadi tidak objektif untuk diukur dalam pembelajaran.

Dengan demikian, hasil analisis dari ketiga alat ukur penelitian di atas telah menunjukkan diantaranya: pertama, capaian hasil belajar mahasiswa setelah dibelajarkan dengan cara mengoptimalkan penggunaan media social dan audiovisual tidak menunjukkan prestasi nilai yang signifikan pada mata kuliah media pembelajaran terutama mata kuliah statistika Pendidikan; kedua, peneliti menemukan adanya kekuatan dan kelemahan (lihat tabel 3) atas penggunaan kedua media ini pada mahasiswa Bahasa Indonesia dan Inggris, Ketiga, peneliti memperoleh pemahaman tentang pentingnya penguasaan teknologi dalam pembelajaran, terutama fungsi dan tujuan penggunaan media. Karena sejalan dengan perkembangan zaman maka kualitas mengajar mahasiswa (calon guru) tidak hanya diukur berdasarkan satu bidang keahlian/ keilmuan saja, melainkan juga bidangbidang lainnya yang terintegritas dengan tuntutan profesi (seperti: Bahasa pemograman computer, mengelola surel); Keempat, memberikan peluang bagi mahasiswa (calo guru) untuk memproduksi suatu bentuk pembelajaran yang inovatif dan dinamis.

Tabel 3. Kelemahan dan Kelebihan Media dalam Penelitian

\begin{tabular}{cll}
\hline Parameter & \multicolumn{1}{c}{ Media Sosial } & \multicolumn{1}{c}{ Media Audiovisual } \\
\hline \multirow{4}{*}{ Kekuatan } & - Praktis & - Real \\
& - Memiliki banyak Brand aplikasi & - Optimal digunakan dalam pembelajaran langsung \\
& - Tanpa batas ruang dan waktu & - Sarana utama pada pertemuan ilmiah \\
& - Menjangkau komunikasi pribadi & - Relatif mahal \\
& - Kuota berbayar dan berpatokan pada kualitas & - Butuh perawatan intensif \\
Kelemahan & - Multifungsi, sehingga dapat membiaskan & - Tidak efisien karen terhubung pada komponen/ \\
& perhatian pembelajar & perangkat lainnya, seperti listrik, kabel \\
& - Intensitas komunikasi yang lebih tinggi daripada & - Harus menguasai tata cara penggunaannya \\
\hline Perilaku & substansinya & - Senang menyaksikan pembelajaran lewat video \\
Mahasiswa & - Senang berinteraksi dengan banyak orang & - Meningkatkan kompetensi mengajar di depan kelas \\
& - Selalu ingin tahu berita & Menambah pengetahuan tentang pengadaan sumber \\
& - Cenderung bebas (berani) berpendapat & belajar \\
& & Cenderung formal sehingga dapat mendisiplinkan \\
& & pembelajar
\end{tabular}




\section{SIMPULAN}

Pada akhirnya hasil penelitian dan pembahasan yang telah dilakukan menghasilkan beberapa temuan yaitu: Hasil belajar mahasiswa setiap jurusan tidak memiliki perbedaan yang signifikan pada mata kuliah media pembelajaran dan statistika pendidikan. Hasil ini dibukitkan melalui uji hipotesis yang menunjukkan harga sig bahwa harga sig. setiap mata kuliah yaitu 0,747 dan 0,132 lebih besar dari harga $\alpha=0,05$. Sehingga meskipun rata-rata hasil belajar mahasiswa setiap jurusan berbeda, tetap saja kemampuan mahasiswa pada kedua mata kuliah ini sama. Terdapat kekuatan dan kelemahan yang media dalam pembelajaran sangat dipengaruhi oleh perilaku belajar mahasiswa dan pengetahuan pendidik tentang materi yang diajar. Tampak bahwa mahasiswa belum dapat menyesuaikan diri dengan pembelajaran melalui optimalisasi penggunaan media, sehingga hasil pengamatan menunjukkan $80,41 \%$ mahasiswa berperilaku negatif selama penelitian, sedangkan perilaku positif sebesar $73,65 \%$. Hasil angket menunjukkan $89,86 \%$ mahasiswa merasa bahwa media sosial dan audiovisual tidak dapat membantu mereka mengoptimalkan potensi yang dimiliki selama masa pandemik ini. Berdasarkan hasil pengamatan dapat diketahui bahwa lebih dari $70 \%$ mahasiswa yang menunjukkan kecenderungan dalam menggunakan media sosial selama berinteraksi dengan dosen dan pada media audiovisual, mahasiswa perlu mengopimalkannya melalui diskusi dan pembelajaran langsung dalam memproduksi media.

\section{DAFTAR RUJUKAN}

Budiningsi, Asri. 2005. Belajar dan Pembelajaran. Jakarta: Rineka Cipta

Heinich, R. et al. 2002. Instructional Media and Technology for Learning, 7th edition. New Jersey: Prentice Hall, Inc

Kaplan, A. M. and Haenlein, M. 2010. User of the World, Unite! The Challenges and opportunities of Social Media. Business Horizons AECT. 1977. The Definition of Educational Technology. Washington: Association for Educational Communication and Tecnology

Sanjaya, Wina. 2014. Media Komunikasi Pembelajaran. Jakarta: Kencana Preanada

Setiawan, Nugraha. 2007. Penentuan Ukuran Sampel Memakai Rumus Slovin dan Tabel Krejcie Morgan: Telaah Konsep dan Aplikasinya. Diskusi Ilmiah Jurusan Sosial Ekonomi Fakultas Peternakan UNPAD, diakses 22/07/2019.

Sugiyono. 2011. Metode Penelitian Kuantitatif Kualitatif Dan $R \& D$. Bandung: Alfabeta. 